\title{
CREATIVITY, PERFORMANCE AND EMOTIONAL BALANCE
}

\author{
Gabriela KELEMEN, Ph.D., \\ Faculty of Educational Science, Psychology and Social Sciences, \\ "Aurel Vlaicu" University of Arad, Romania \\ gabriela.kelemen 0 uav.ro
}

Abstract: Creativity is one of the cognitive skills required by performance in the $21^{\text {st }}$ century. In the current society which is fully technological and tends to automatize everything, no one can deny the importance of creativity as necessary and useful attribute of knowledge. However, there are different ways of approaching it due to its features that are like a magical aspect of thinking (Sparks, 2011, p. 3). ${ }^{2}$ Studies have highlighted that there is mutual determination between creativity as specific, innovative and emotional intelligence. A person is considered creative if s/he can produce original, innovative, unique ideas or products. Creative thinking allows a person to explore different aspects of life in completely different ways than the common way of thinking. A manner of analysing the creative phenomenon is to observe creative personalities, to identify the cognitive characteristics that are different from the others such as creative strategies, cognitive styles, resolving strategies, overwhelming imagination, inspiration, intuition and other elements (Piirto, 2011). Rational mind is the one that confers understanding and reflection along with emotional experiences that put their mark on human personality and thinking. Creativity is a skill that can be developed in schools, if it is identified and proper strategies are used such as engaging the individual in his/her own development with all the abilities along with presenting all opportunities for social evolution.(Glassner \& Schwarz, 2007).

Key words: Creativity, Emotional Intelligence, identification, formative intervention

\footnotetext{
${ }^{2}$ S. Sparks, Science looks at how to inspire creativity. Education Week, 201131(14), 1-16, p.3

${ }^{3}$ A., Glassner, \& B. B. Schwarz, What stands and develops between creative and critical thinking? Argumentation? Thinking Skills and Creativity, 20072, 10-18.
} 


\section{Literature review}

Creativity, a psychological context difficult to define and operationalize bears defining components in itself. The first one is novelty, originality and the uniqueness of thought or product created. The second aspect refers to their relevance in socio-cultural plan.

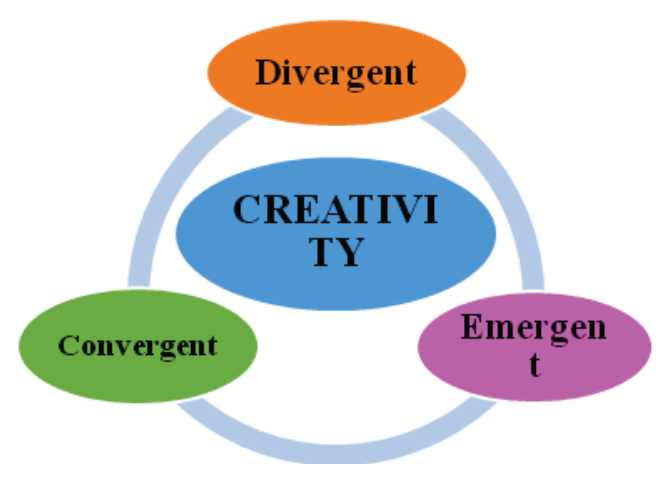

Figure no.1.The creative thinking

Creativity lies at the intersection of the dynamic interaction of the cognitive components of general intelligence and the aptitude attributes. One of the most appropriate definitions is the following: "a mental process by which an individual creates new ideas or products, or recombines existing ideas and products, in a fashion that is novel to him or her" (Gallagher \& Gallagher, 1994, p. 319). ${ }^{4}$

All researchers in the field agree that the features that someone can identify in a creative person are: fluency, flexibility, originality and complexity of ideas. Fluency refers to the quality of thinking, flexibility refers to applicability of an idea under various aspects, originality refers to how unique the idea is. Developing creativity depends on many factors, often random (European University Association). Creative imagination is an important component of creativity that leads to the integration of empirical knowledge into logical reasoning, cognitive strategies duplicated by features such as intuition and understanding, found in success and performance. Harvard Gardner when referring to annotation creativity: "When I examine myself and my methods of thought I come to the conclusion that the gift of fantasy has meant more to me than my talent for absorbing positive

\footnotetext{
${ }^{4}$ J. J., Gallagher, \& S. A. Gallagher, Teaching the gifted child (4th ed.). Boston, MA: Allyn \&Bacon, 1994, p.319.
} 
knowledge" (Gardner, 1993, p. 105). Intuition is a feature of creative personality; which human understanding cannot reasonably explain. What is intuition? It is a mental illumination that is simply present there and triggers a flashing reaction to some events, actions and phenomena independent of rational thinking. Intuition occurs when the concerns in solving a problem persist and happen instantly, as a mental flashing and lead to new levels of knowledge in research. Innovation, intuition is a rapid passage across the boundaries of investigation and determines the selection of the most appropriate information in solving a problem by using the most appropriate information kept in memory (Gordon and Berger 2003). Emotional intelligence refers to the ability to understand feelings and emotions and to manage them so as to contribute to performance. Howard Gardner in his Frame of mind $^{5}$, defined the human being as composed of several types of intelligence. A relationship of self-dignity is created between intelligence and feeling. Emotional intelligence, as Goleman calls it in his book "Emotional Intelligence" $(1995)^{6}$, reminds of illogical pulses that are imprinted on successes in everyday life. Appropriate management of emotions contributes substantially to increased school performance, so teachers have a duty to know the well-being of their learners and to take into account their particularities. Emotional intelligence helps to increase the learners' creativity in the context of understanding and addressing them according to their own development needs.

\section{How to flourish creativity in classroom}

Activity is guided in any classroom by a teacher who has to achieve certain objectives according to the curriculum, and within limited teaching time. Even homogeneous classes are made up of individualities, each with its aptitude, with the specificity of thought, with its own rhythm of solving the learning task. As the focus is generally placed on memorizing formulas and definitions, somehow creative thinking and creative skills are placed secondly. Learners with special intellectual and creative skills are emotionally sensitive and affected by the lack of feedback and personal valuation and will experience a serious negative impact in such situations. Individualized learning, sufficient time for learners to express their ideas, capitalizing on and encouraging the most innovative approaches to classroom problems, are the incubator for developing creativity. Another feature of the creative personality is the asynchronous development between

\footnotetext{
${ }^{5} \mathrm{H}$. Gardner, Frames of Mind: The Theory of Multiple Intelligences. New York: Basic Books. 1991/2011

${ }^{6}$ D. Goleman, Emotional intelligence. New York: Bantam Books. 1995
} 
intellectual, creative and social-emotional skills. These learners need affective reinforcement, encouragement, to improve self-esteem, selfawareness, identification with others like-minds. In this respect, it is necessary:

-to pay more attention to the learners` affective needs;

- to introduce in schools a day when students work freely on their own projects $^{7}$;

- to place learners in learning situations where to compare and find similarities and differences;

- to classify objects based on their own criteria;

- to make analogies;

- to create metaphors that highlight the relationships between objects and concepts ${ }^{8}$.

If educators use interactive methods, learners are able to develop in time mental models based on experiences and permanently enriched in and outside school through non-formal activities, permanently making the transfer of knowledge and skills from one domain to another, combinatorial conjunctions $^{9}$ in educational practice. Using these working tools, educators better understand concepts and relationships between them and manage to adapt them to other totally different areas.

\section{Study methodology}

Measuring a person's level of creativity is a difficult task for which conventional, standardized instruments that involve a great deal of subjectivism cannot be used. Teresa Amabile, professor and psychologist, designed at Harvard University in 1982 The Consensual Assessment technique, based on the use of experts (judges) in the field. The purpose is to make the assessment more objective ${ }^{10}$. Her method was called-gold standard. We have conducted a study on the relationship between the development of creativity and the learners' effective emotional level with students from Primary and pre-school education study programme, students who are preparing to become teachers for early education and early schooling. We

\footnotetext{
${ }^{7}$ K. Petty, Reflections on the $20 \%$ project. Retrieved from The Tech Classroom 2013, March 20. website:

http://www.thetechclassroom.com/20-project/reflections-on-the-20-project

${ }^{8} \mathrm{~S}$. Glynn, The teaching with analogies model: Build conceptual bridges with mental models. Science and Children, 44(2007), 8 52-55.

${ }^{9} \mathrm{P}$. Thagard, Creative combination of representations: Scientific discovery and technological invention. In R. Proctor \& E. J. Capaldi (Eds.), Psychology of science. Oxford, England: Oxford University Press, 2010.

${ }^{10} \mathrm{http}: / /$ www.creativehuddle.co.uk/the-consensual-assessment-technique (accessed 17.09.2016)
} 
used the Torrance's test of Creative Thinking (TTCT) ${ }^{11}$ and Thinking Creatively with words (TTCT) testing samples to identify the pupils creativity level in grades 1-4. Students had the task to reflect upon their life experiences and then draw a picture with reference to them. Through these tests, the level of fluency of thinking, the design of the drawing based on critical thinking, the originality of the drawings, the perseverance for completing the required task and the abstraction ability in defining the drawing were followed. (Trait Emotional Intelligence Questionnaire - Child Form) (TEIQue-CF) (S. Mavroveli \& K. V. Petrides, Institute of Education, University of London) ${ }^{12}$

3. Results and DiscussionTable no.1. Torrance's test of Creative Thinking (TTCT)

\begin{tabular}{|c|l|l|l|l|l|}
\hline No & The Figural TTCT & $\begin{array}{l}\text { Pre-test } \\
\text { Mean (SD) }\end{array}$ & $\begin{array}{l}\text { Post-tests } \\
\text { Mean (SD) }\end{array}$ & $\mathrm{t}$ & $\mathrm{P}$ \\
\hline 1. & $\begin{array}{l}\text { emotional } \\
\text { expressiveness }\end{array}$ & 3.9 & 8.4 & .25 & .54 \\
\hline 2. & $\begin{array}{l}\text { storytelling } \\
\text { articulateness }\end{array}$ & 9.7. & 16.7 & .24 & .43 \\
\hline 3. & $\begin{array}{l}\text { movement or action } \\
4 .\end{array}$ & 7.9 & 12.3 & .25 & .32 \\
\hline 5. & $\begin{array}{l}\text { expressiveness of titles } \\
\text { fynthesis of incomplete }\end{array}$ & 10.3 & 14.0 & .17 & .26 \\
\hline 6. & $\begin{array}{l}\text { synthesis of lines or } \\
\text { circles }\end{array}$ & 8.3 & 12.0 & .19 & 51 \\
\hline 7. & unusual visualization & 6.7 & 13.0 & .24 & .64 \\
\hline 8. & internal visualization & 8.0 & 12.0 & .16 & .45 \\
\hline 9. & $\begin{array}{l}\text { extending or breaking } \\
\text { boundaries }\end{array}$ & 9.7 & 16.7 & .18 & .37 \\
\hline 10. & humour & 7.0 & 11.7 & .23 & .52 \\
\hline 11. & richness of imagery & 8.3 & 13.0 & .25 & .37 \\
\hline 12. & colourfulness of imagery & 8.6 & 12.3 & .18 & .56 \\
\hline 13. & fantasy & 9.9 & 16.7 & .15 & .21 \\
\hline
\end{tabular}

Table no.2.The Verbal TTCT: Thinking Creatively with Words

\begin{tabular}{|l|l|l|l|l|l|}
\hline No & The Figural TTCT & $\begin{array}{l}\text { Pre-test Mean } \\
(\mathrm{SD})\end{array}$ & $\begin{array}{l}\text { Post-tests Mean } \\
(\mathrm{SD})\end{array}$ & $\mathrm{t}$ & $\mathrm{p}$ \\
\hline 1. & fluency & .043 & .23 & .32 & .46 \\
\hline
\end{tabular}

\footnotetext{
${ }^{11}$ http://www.ststesting.com/ngifted.html (accessed 21.09.2016)

${ }^{12}$ http://www.psychometriclab.com/Home/Default/14 (accessed 20.09.2016)
} 


\begin{tabular}{|l|l|l|l|l|l|}
\hline 2. & flexibility & .098 & .31 & .65 & .87 \\
\hline 3. & originality & .061 & .75 & .39 & .70 \\
\hline
\end{tabular}

After the identification of creative students, we have intervened through methods of stimulating creative students by giving them emotional support, by providing feedback, through discussions with students towards their own achievements, through constant stimulation and encouragement.

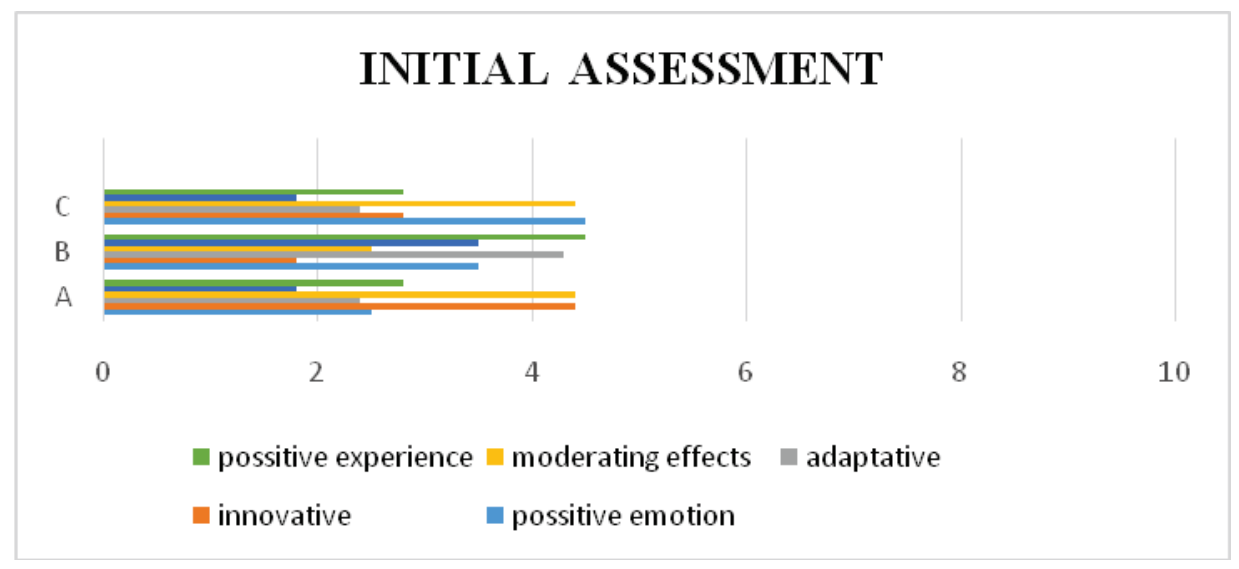

Fig.no.2.Initial assessment of students assessment

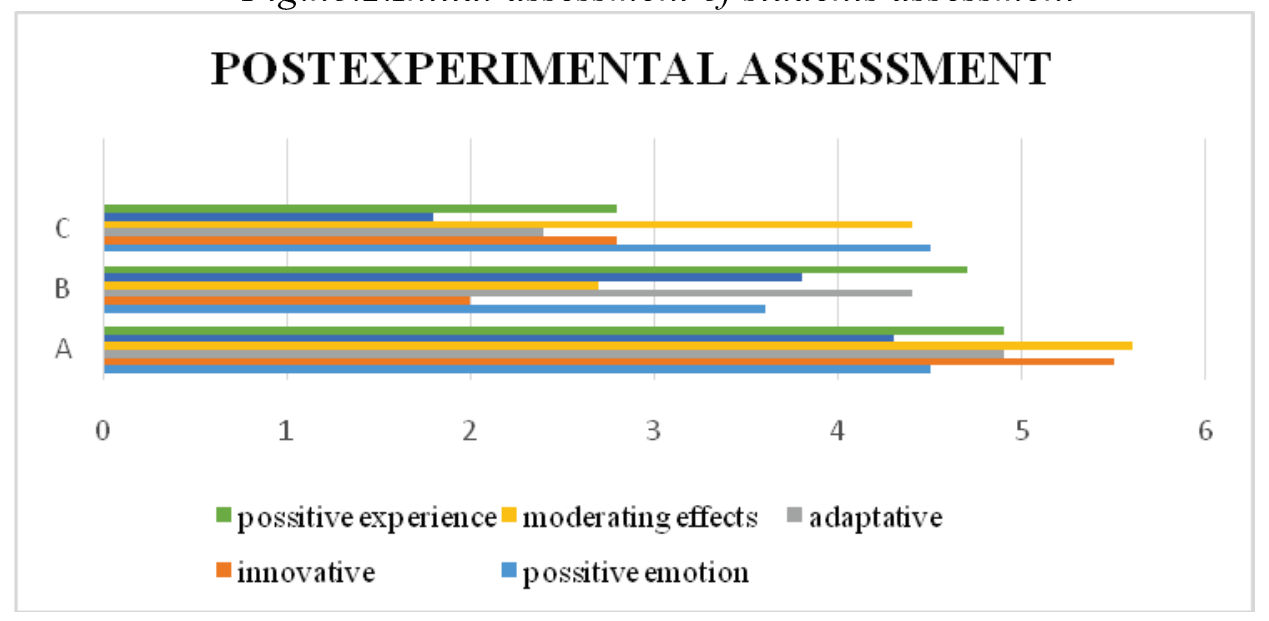

Fig.no.3.1.Postexperimental assessment of student's assessment

To determine the importance of emotional support for creative students, we have used the five elements of differentiation between the experimental group and the control group. After analysing the solutions for the five variables: positive experience, moderating effects, adaptive experience, 
innovative response and positive emotion according to the analysed percentage we can assume an increase in the adaptability level and positive reactions in the program offered to the experimental group that received a constant affective support. Students helped the pupils involved in the study, thus facilitating the development of emotional aspects. The results of the study reveal the importance of emotional support given by an informed person, encouragement, morale, permanent highlighting of the positive aspects of the usual behaviour of creative students. Affective support is the defining key in developing the skills of creative learners. There are significant differences between students, some methods are suitable for certain students, and others need to be readjusted according to their individual peculiarities. The study has confirmed the importance of emotional support.

\section{Conclusions}

Learners, so different from each other, are capable of original discovery, original creations, creative thinking. Everything depends on how educators find the most appropriate methods to stimulate their native giftedness and lead them to maximum development. It has been found that the dynamic interaction between personality, cognitive, emotional and psychomotor traits in stimulating and motivating conditions leads to the assertion of learners` creative skills in their area of giftedness. Creativity is an act, an idea, a product that can change a field and turn reality in a positive meaning (Mihaly Csikszentmihalyi). Creative learners are visionary, have a great curiosity and the ability to make connections beyond the capacity of others by asking questions, observing, exploring, reviewing and analysing in detail the different phenomena and events. Introvert and bent to perfection, creative people need constant emotional support and encouragement.

\section{References:}

Amabile, T. M. (1982). Social psychology of creativity: A consensual assessment technique. Journal of personality and social psychology, 43, 997-1013.

Amabile, T. M., Goldfarb, P., \& Brackfleld, S. C. (1990). Social influences on creativity: Evaluation, coaction, and surveillance. Creativity Research Journal, 3, 6-21.

Batey, M. \& Furnham, A. (2006). Creativity, intelligence, and personality: A critical review of the scatteredliterature. Genetic, Social, and General Psychology Monographs, 132, 355-429.

Byrne, C. (2011). Task selection and the consensual assessment technique: Using collage tasks in creativity research (MA Thesis). Retrieved from http://www.uclan.ac.uk/schools/adp/just_published.phpCollins, M. A., \& 
Amabile, T. M. (2011). Motivation and creativity. In R. J. Sternberg (Ed.), Handbook of creativity (pp. 297-312). New York, NY: Cambridge University Press.

Davis, G. A., Rimm, S. B., \& Siegle, D. (2011). Education of the gifted and talented (6th ed.). Boston, MA: Pearson.

Melissa K. Demetrikopoulos, Interplay of Creativity and Giftedness in Science, Edited by

Institute for Biomedical Philosophy,Sense Publishers,P.O. Box 21858,3001 AW Rotterdam, The Netherlands

Furnham, A. (2016). The Relationship between Cognitive Ability, Emotional Intelligence and Creativity.Psychology, 7, 193-197. http://dx.doi.org/10.4236/psych.2016.72021

Gallagher, J. J., \& Gallagher, S. A. (1994). Teaching the gifted child (4th ed.). Boston, MA: Allyn \&Bacon.

Gardner, H., (1991/2011), Frames of Mind: The Theory of Multiple Intelligences. New York: Basic Books..

Glassner, A., \& Schwarz, B. B. (2007). What stands and develops between creative and critical thinking?Argumentation? Thinking Skills and Creativity, 2, 10-18.

Glynn, S. (2007). The teaching with analogies model: Build conceptual bridges with mental models. Science and Children, 44(8), 52-55.Goleman, D. (1995). Emotional intelligence. New York: Bantam Books.

Hay Chris, Knowledge, Creativity and Failure. A New Pedagogical Framework for Creative Arts. Palgrave Macmillan, Springer International Publishing AG Switzerland.

Hollingsworth, R. (2012). Factors associated with scientific creativity. Euresis Journals, 2(Winter),

77-112.

Lee, S.-Y., \& Olszewski-Kubilius, P. (2006). The emotional intelligence, moral judgment, and leadership of academically gifted adolescents. Journal for the Education of the Gifted, 30, 29-67.

Novak, J. D. (2010). Learning, creating, and using knowledge: Concept maps as facilitative tools in schools and corporations. Journal of e-Learning and Knowledge Society, 6(3), 21-30.

Petty, K. (2013, March 20). Reflextions on the 20\% project. Retrieved from The Tech Classroom website:

http://www.thetechclassroom.com/20-project/reflections-on-the-20-project.

Reis, S. M., \& Renzulli, J. S. (2010). Is there still a need for gifted education? An examination of current research. Learning and Individual Differences, 20(4), 308-317. doi: 10.1016/j.lindif.2009.10.012

Sparks, S. (2011). Science looks at how to inspire creativity. Education Week, 31(14), 1-16. 
Sternberg, R.J. (2015). Teaching for Creativity: The Sounds of Silence. Psychology of Aesthetics, Creativity, and the Arts (in press).

Thagard, P. (2010). Creative combination of representations: Scientific discovery and technological invention. In R. Proctor \& E. J. Capaldi (Eds.), Psychology of science. Oxford, England: Oxford University Press.

Ambrose D., Sternberg R. J., Renzulli, J., S., (2016), Creative Intelligence in the 21st Century, Sense Publishers 